\title{
Article
}

Mycosphere

\section{Novel fungal species of Phaeosphaeriaceae with an asexual/sexual morph connection}

Karunarathna $A^{1,2,3,4,5}$, Papizadeh $M^{6}$, Senanayake $I^{3,4,5}$, Jeewon $R^{7}$, Phookamsak $R^{1,3,4,5}$, Goonasekara $\mathrm{ID}^{3,4,5}$, Wanasinghe $\mathrm{DN}^{3,4,5}$, Wijayawardene $\mathrm{NN}^{5}$, Amoozegar MA ${ }^{8}$, Shahzadeh Fazeli $\mathrm{SA}^{6,9}$, Camporesi $\mathrm{E}^{10,11}$, Hyde $\mathrm{KD}^{1,3,4,5}$, Weerahewa HLD ${ }^{12}$, Lumyong $S^{1}$, McKenzie EHC ${ }^{1,13^{*}}$

\footnotetext{
${ }^{1}$ Department of Biology, Faculty of Science, Chiang Mai University, Chiang Mai 50200, Thailand.

${ }^{2}$ Department of Entomology and Plant Pathology, Faculty of Agriculture, Chiang Mai University, Chiang Mai 50200, Thailand.

${ }^{3}$ World Agroforestry Centre, East and Central Asia, 132 Lanhei Road, Kunming 650201, Yunnan, People's Republic of China.

${ }^{4}$ Key Laboratory for Plant Diversity and Biogeography of East Asia, Kunming Institute of Botany, Chinese Academy of Sciences, 132 Lanhei Road, Kunming 650201, People's Republic of China.

${ }^{5}$ Centre of Excellence in Fungal Research, Mae Fah Luang University, Chiang Rai 57100, Thailand.

${ }^{6}$ Microorganisms Bank, Iranian Biological Resource Centre (IBRC), Academic Centre for Education, Culture and Research (ACECR), Tehran, Iran.

${ }^{7}$ Department of Health Sciences, Faculty of Science, University of Mauritius, Reduit, Mauritius.

${ }^{8}$ Extremophiles Laboratory, Department of Microbiology, Faculty of Biology and Centre of Excellence in Phylogeny of Living Organisms, College of Science, University of Tehran, Tehran, Iran.

${ }^{9}$ Department of Molecular and Cellular Biology, Faculty of Basic Sciences and Advanced Technologies in biology, University of Science and Culture, Tehran, Iran.

${ }^{10}$ A.M.B. Gruppo Micologico Forlivese "Antonio Cicognani”, Via Roma 18, Forli, Italy.

${ }^{11}$ A.M.B. Circolo Micologico "Giovanni Carini”, C.P. 314 Brescia, Italy.

${ }^{12}$ Department of Botany, The Open University of Sri Lanka, Nawala, Nugegoda, Sri Lanka.

${ }^{13}$ Landcare Research New Zealand, Private Bag 92170, Auckland Mail Centre, Auckland 1142, New Zealand
}

Karunarathna A, Papizadeh M, Senanayake IC, Jeewon R, Phookamsak R, Goonasekara ID, Wanasinghe DN, Wijayawardene NN, Amoozegar MA, Shahzadeh Fazeli SA, Camporesi E, Hyde KD, Weerahewa HLD, Lumyong S, McKenzie EHC 2017 - Novel fungal species of Phaeosphaeriaceae with an asexual/sexual morph connection. Mycosphere 8(10), 1818-1834, Doi 10.5943/mycosphere/8/10/8

\begin{abstract}
We are studying Dothideomycetes from different hosts in different geographical regions and have introduced new taxa from China, Iran and Italy. In this paper, we introduce Yunnanensis gen. nov. on Poaceae from Yunnan Province, in China, to accommodate Y. phragmitis sp. nov. Neosetophoma iranianum sp. nov. recovered from soil in Iran is also introduced and a sexual morph of Wojnowicia dactylidis on Asperula sp. (Rubiaceae) collected in Italy is also reported. DNA sequence based phylogenies (ribosomal gene) are also generated to infer potential taxonomic relationships. Yunnanensis is morphologically distinct from other genera in Phaeosphaeriaceae in having ascomata with evenly thickened walls comprising with textura angularis and textura angularis to textura prismatica inner layers, broadly cylindrical to cylindric-clavate asci, muriform ascospores with a mucilaginous sheath and a coelomycetous asexual state with muriform conidia. Phylogeny also supports Yunnanensis as a novel genus basal to Neosetophoma. Neosetophoma
\end{abstract}


iranianum is distinct from other species in having subglobose, ovoid to tear-drop shaped transversely septate; biseptate to triseptate conidia. Neosetophoma iranianum is closely related to $N$. lunariae but DNA sequence data differences are sufficient to segregate them as two species. Another interesting finding are the asexual/sexual morph connections in Yunnanensis phragmitis and Wojnowiciella dactylidis. All novel taxa investigated herein belong to the family Phaeosphaeriaceae.

Key words - Dothideomycetes - graminicolous fungi - muriform - Neosetophoma - Pleosporales - soil fungi -Yunnanensis - Wojnowiciella.

\section{Introduction}

Recent studies on taxonomy and phylogeny of fungi on Poaceae in Yunnan Province in China and Italy revealed many new taxa, especially within the family Phaeosphaeriaceae in Pleosporales (Thambugala et al. 2017). Pleosporales, the largest order in Dothideomycetes and comprises 55 families based on multi-gene phylogenetic analyses (Liu et al. 2017). Recent publications have revisited and clarified the taxonomy of several members of this important order, e.g. Cucurbitariaceae (Papizadeh et al. 2017a, Wanasinghe et al. 2017b), Massarineae (Phukhamsakda et al. 2016), Phaeosphaeriaceae (Phookamsak et al. 2014a) and Pleosporineae (Wanasinghe et al. 2017a). Phylogenetic studies have shown that Phaeosphaeriaceae is a heterogeneous assemblage of genera. Species in Phaeosphaeriaceae can be endophytic, epiphytic or saprobic, especially on monocotyledons (e.g. Cannaceae, Cyperaceae, Juncaceae, Poaceae) (Hyde et al. 2013, Phookamsak et al. 2014b). Species have also been reported as pathogens causing leaf spots on various hosts (Quaedvlieg et al. 2013, Phookamsak et al. 2014a, Li et al. 2016). In a recent study of fungi on grasses, Thambugala et al. (2017) introduced a new genus and 15 new species in the family Phaeosphaeriaceae.

Grasses (Poaceae) are ecologically dominant, monocotyledonous plants, with a cosmopolitan distribution (Thambugala et al. 2017). Grasses provide a major example of standing litter in many temperate and tropical countries and fungi are important in their decay process (Poon \& Hyde 1998, Wong \& Hyde 2001, Purahong \& Hyde 2011). Thus, Poaceae is a family that could be expected to harbor many new fungal species (Hawksworth \& Rossman 1997).

The current study was initiated to find and to describe new taxa from various substrates and hosts. In this paper, a new grass inhabiting genus, Yunnanensis is introduced to accommodate $Y$. phragmitis sp. nov. Neosetophoma iranianum sp. nov. in wet land soil is also introduced. The sexual/asexual morphs of Wojnowicia dactylidis and for Yunnanensis phragmitis are described. All taxonomic arrangements proposed herein are supported with DNA sequence analysis.

\section{Materials \& Methods}

\section{Plant sample collection, morphological studies and isolation}

Fresh grass specimens were collected from Erhai Lake, Dali, in Yunnan Province, China; grass litter was collected from Botanical Garden of Kunming Institute of Botany, Kunming, Yunnan, China Dead aerial stems of Asperula sp. (Rubiaceae), were collected from Maestà della Biancarda, Verghereto, Province of Forlì-Cesena [FC], Italy. Specimens were processed and examined following the method described by Wanasinghe et al. (2014a). Hand-cut sections of the fruiting structures were mounted in water for microscopic studies and photomicrography. Specimens were examined with a Nikon ECLIPSE 80i compound microscope and photographed with a Canon EOS 600D digital camera fitted to the microscope. Measurements of morphological characters were made with the Tarosoft $(\mathrm{R})$ Image Frame Work program and images used for figures processed with Adobe Photoshop CS3 Extended version 10.0 (Adobe Systems, USA).

Single spore isolation was carried out following the spore suspension method described in Chomnunti et al. (2014). Germinated spores were individually transferred to potato dextrose agar (PDA) plates and grown at room temperature $\left(10-16^{\circ} \mathrm{C}\right)$. Colony colour and other characters were 
observed and measured after one week and again after three weeks. The specimens were deposited in the Mae Fah Luang University Herbarium (MFLU), Chiang Rai, Thailand and Herbarium of Cryptogams, Kunming Institute of Botany Academia Sinica (HKAS). Living cultures were deposited in the Mae Fah Luang University Culture Collection (MFLUCC) and duplicated at Kunming Institute of Botany Culture Collection (KUMCC).

\section{Soil sample collection, morphological studies and isolation}

Soil samples were collected from the Gomishan wetland, Golestan Province, Iran. One gram $(1 \mathrm{~g})$ of each soil sample was suspended in $10 \mathrm{ml}$ of Ringer solution (Alef \& Nannipieri 1995) and transferred into $250 \mathrm{ml}$ Erlenmeyer flasks containing $50 \mathrm{ml}$ yeast peptone glucose (YPG) broth. Following two hours of incubation on a rotary shaker $(220 \mathrm{rpm})$ at $25{ }^{\circ} \mathrm{C}$ each flask was supplemented with final concentration of $250 \mathrm{mg} / \mathrm{L}$ chloramphenicol. After six hours of incubation, enriched broth cultures were serially diluted in appropriate volumes of $0.96 \%$ saline buffer. The dilutions $(80 \mu \mathrm{l})$ were spread on chloramphenicol containing PDA plates $(250 \mathrm{mg} / \mathrm{L})$ and incubated at $25{ }^{\circ} \mathrm{C}$ up to 5 days. Emerging fungal isolates were purified by hyphal tipping. Finally, brownspored and hyaline conidia coelomycetes were screened and selected on oat agar (OA) medium for identification (Papizadeh et al. 2017a). The specimens were deposited in the Herbarium of the Plant bank, Iranian Biological Resource Center (IBRC). Living cultures were deposited at the Microorganisms bank of Iranian Biological Resource Center.

Facesoffungi (FoF) and Index Fungorum numbers (IF) were acquired as in Jayasiri et al. (2015a) and Index Fungorum (2017). The new species were established based on recommendations in Jeewon \& Hyde (2016).

\section{DNA extraction, PCR amplification and sequencing for fungal isolates from plant materials}

Genomic DNA was extracted from fresh fungal mycelium grown on PDA media at $16{ }^{\circ} \mathrm{C}$ for 4 weeks using the Biospin Fungus Genomic DNA Extraction Kit (BioFlux®, Hangzhou, P. R. China) following the instructions of the manufacturer.

The DNA amplification was performed by polymerase chain reaction (PCR) for the partial sequences of three genes, the internal transcribed spacers (ITS1, 5.8S, ITS2), small subunit rDNA (SSU) and large subunit (LSU). The ITS gene was amplified using the primers ITS5 and ITS4 (White et al. 1990), the LSU region was amplified using the primer pair LROR and LR5 (Vilgalys \& Hester 1990), SSU was amplified using the primers NS1 and NS4 (White et al. 1990). Polymerase chain reaction (PCR) was carried out following the protocol of Phookamsak et al. (2014a). The quality of PCR amplification was confirmed on $1 \%$ agarose gels electrophoresis stained with ethidium bromide. The amplified PCR fragments were sent to a commercial sequencing provider (Shanghai Sangon Biological Engineering Technology \& Services Co., Shanghai, P.R. China). The nucleotide sequence data acquired were deposited in GenBank (Table 1).

\section{DNA extraction, PCR amplification and sequencing for fungal isolates from soil}

Genomic DNA was extracted from fresh fungal mycelium by using salting-out protocol (Papizadeh et al. 2017a, Saba et al. 2016a, b). The DNA amplification was performed by polymerase chain reaction (PCR) for the internal transcribed spacers (ITS1, 5.8S, ITS2) and large subunit (LSU). The ITS regions were amplified using the primers ITS5 and ITS4 (White et al. 1990), the LSU region was amplified using the primer pair LROR and LR5 (Vilgalys \& Hester 1990). PCR reactions for amplification of the ITS and LSU fragments entailed 30 cycles $\left(94{ }^{\circ} \mathrm{C}\right.$ for $45 \mathrm{~s}, 56{ }^{\circ} \mathrm{C}$ for $40 \mathrm{~s}, 72{ }^{\circ} \mathrm{C}$ for $95 \mathrm{~s}$ and one additional cycle with a final $12 \mathrm{~min}$ chain elongation). The amplified PCR fragments were sent to a commercial sequencing provider (Genfanavaran Biotech Corporation, Tehran, Iran). The nucleotide sequence data acquired were deposited in GenBank (Table 1).

\section{Phylogenetic analyses}


Phylogenetic analyses were conducted based on a combined gene of ITS LSU and SSU sequence data. The topologies of the trees obtained from each gene were compared prior to combined gene analysis to check for any incongruence in overall topology. The reference nucleotide sequences (Table 1) of representative genera in Phaeosphaeriaceae were retrieved from GenBank and recently published data (Thambugala et al. 2017). The single gene sequences were initially aligned by MAFFT V.7.036 (http://mafft.cbrc.jp/alignment/server/) (Katoh et al. 2017), improved manually where necessary and multiple alignments were combined using Bioedit v.7.2 (Hall 1999).

Maximum parsimony (MP) analysis was carried with the heuristic search option in PAUP (Phylogenetic Analysis Using Parsimony) v. 4.0b10 (Swofford 2002). Parsimony bootstrap analyses were performed using the full heuristic search option, random stepwise addition, and 1000 replicates, with maxtrees set at 1000. Descriptive tree statistics for parsimony (Tree Length [TL], Consistency Index [CI], Retention Index [RI], Relative Consistency Index [RC] and Homoplasy Index $[\mathrm{HI}]$ were calculated for trees generated under different optimality criteria. The Kishino Hasegawa tests (Kishino \& Hasegawa 1989) were performed to determine whether the trees inferred under different optimality criteria were meaningfully different.

Evolutionary models for phylogenetic analyses were selected independently for each locus using MrModeltest v. 3.7 (Nylander 2004) under the Akaike Information Criterion (AIC) implemented in both PAUP v. $4.0 \mathrm{~b} 10$ and MrBayes v. 3. Phylogenetic reconstructions of combined gene trees were performed using Maximum likelihood (ML), Maximum parsimony (MP) and Bayesian Inference (BI) criteria.

Maximum likelihood trees were generated using the RAxML-HPC2 on XSEDE (8.2.8) (Stamatakis et al. 2008, Stamatakis 2014) in the CIPRES Science Gateway platform (Miller et al. 2010) using GTR $+\mathrm{I}+\mathrm{G}$ model of evolution. The robustness of the most parsimonious tree is estimated based on 1000 bootstrap replications.

Bayesian Inference (BI) analysis was conducted with MrBayes v. 3.1 .2 (Huelsenbeck \& Ronquist 2001) to evaluate posterior probabilities (BYPP) (Rannala \& Yang 1996, Zhaxybayeva \& Gogarten 2002) by Markov Chain Monte Carlo sampling (BMCMC). Two parallel runs were conducted, using the default settings, but with the following adjustments: Six simultaneous Markov chains were run for 2,000,000 generations and trees were sampled every 200th generation. The distribution of log-likelihood scores will examine to determine stationary phase for each search and to decide if extra runs were required to achieve convergence, using Tracer v. 1.6 program (Rambaut et al. 2014). First $10 \%$ of generated trees representing the burn-in phase were discarded and the remaining trees were used to calculate posterior probabilities of the majority rule consensus tree.

Phylograms were visualized with FigTree v1.4.0 program (Rambaut 2012) and reorganized in Microsoft Power Point (2016) and Adobe Illustrator CS5 (Version 15.0.0, Adobe, San Jose, CA). The finalized alignment and tree is deposited in TreeBASE, submission ID: 21506 (http://www.treebase.org/).

\section{Results}

\section{Phylogeny}

The combined LSU, SSU and ITS gene dataset comprised 40 taxa, including new taxa and other taxa from Phaeosphaeriaceae (Fig. 1). Phylogenetic trees obtained from ML, MP and BI analyses yielded trees with similar overall topologies at the generic level and are in agreement with previous studies (Thambugala et al. 2017).

The RAxML analysis of the combined dataset yielded a best scoring tree (Fig. 1) with a final ML optimization likelihood value of -8529.433312. The matrix had 530 distinct alignment patterns, with $16.12 \%$ of undetermined characters or gaps. Parameters for the GTR + I + G model of the combined LSU, SSU and ITS were as follows: Estimated base frequencies; $\mathrm{A}=1.000000, \mathrm{C}=$ $0.250109, \mathrm{G}=0.214268, \mathrm{~T}=0.269196$; substitution rates $\mathrm{AC}=0.645067, \mathrm{AG}=1.598602, \mathrm{AT}=$ 2.987397, $\mathrm{CG}=2.504999, \mathrm{CT}=0.702586, \mathrm{GT}=5.959707$; proportion of invariable sites $\mathrm{I}=$ 


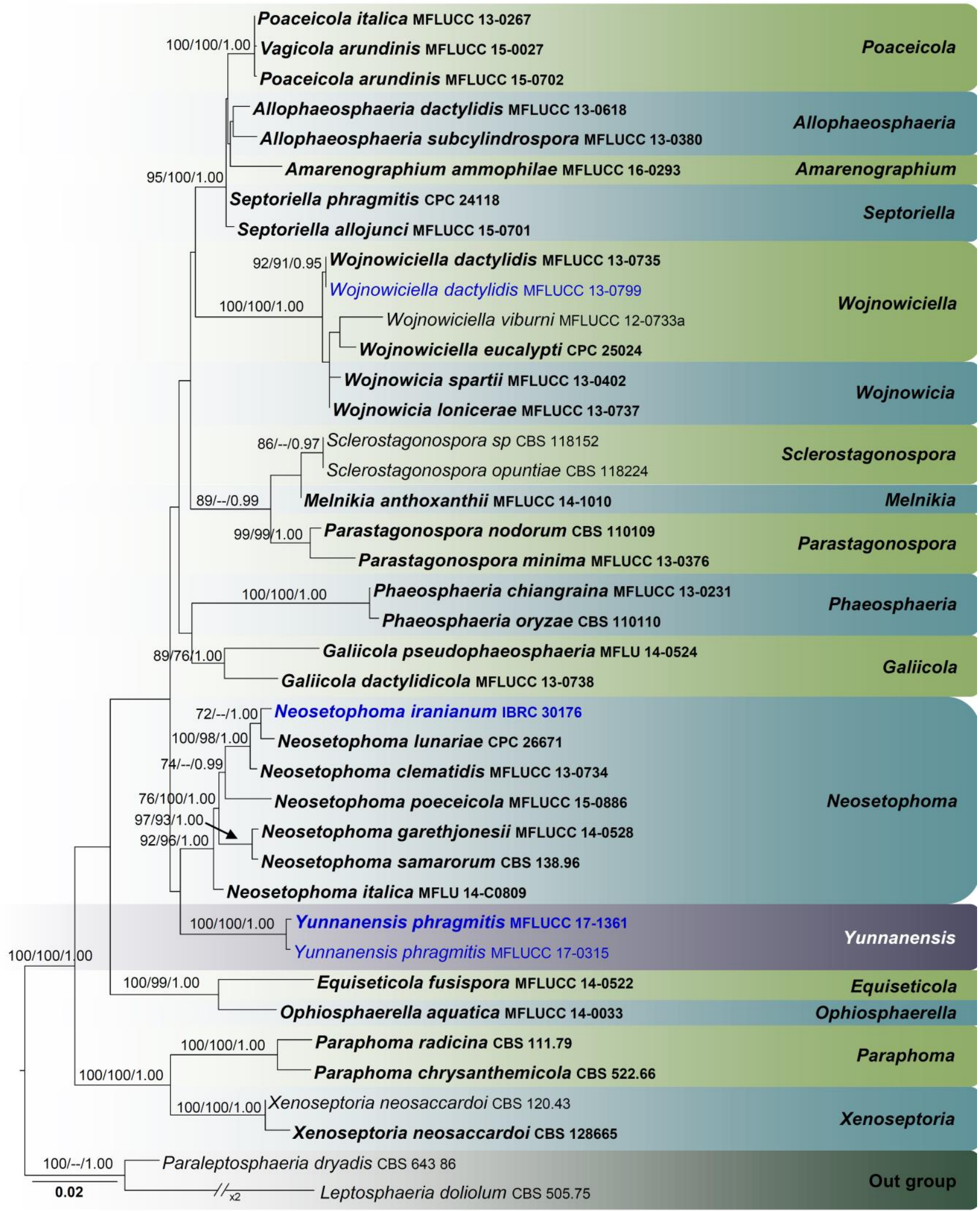

Figure 1 - RAxML tree based on a combined dataset of LSU, SSU and ITS partial sequences. Bootstrap support values for maximum likelihood (ML) higher than $60 \%$, maximum parsimony (MP) higher than $60 \%$, and Bayesian posterior probabilities (BYPP) greater than 0.90 are displayed as above the nodes respectively. The ex-type strains are in bold. Newly generated sequences are indicated in blue. The tree is rooted to Leptosphaeria doliolum (CBS 505.75) and Paraleptosphaeria dryadis (CBS 643.86). 
0.001000; gamma distribution shape parameter $\alpha=0.576450$. The maximum parsimony dataset consisted of 2441 characters, of which 2113 were constant, 256 parsimony-informative and 72 parsimony-uninformative. The parsimony analysis of the data matrix resulted in 4 equally most parsimonious trees with a length of 948 steps $(\mathrm{CI}=0.538, \mathrm{RI}=0.727, \mathrm{RC}=0.391, \mathrm{HI}=0.462)$ in the first tree. The Bayesian analysis resulted in 10001 trees after 2000000 generations. The first 1000 trees, representing the burn-in phase of the analyses, were discarded, while the remaining 9001 trees were used for calculating posterior probabilities in the majority rule consensus tree. The average standard deviation of split frequencies was 0.010067 .

\section{Taxonomy}

In this section the new genus Yunnanensis with a single new species Yunnanensis phragmitis, the new species Neosetophoma iranianum and the sexual morph of Wojnowicia dactylidis are illustrated and described.

Yunnanensis A. Karunarathna, Phookamsak \& K. D. Hyde, gen. nov.

Index Fungorum number: IF553842; Facesoffungi number: FoF03725

Etymology - Refers to Yunnan Province, China, where the holotype was collected.

Saprobic on dead grass stems in terrestrial habitats. Sexual morph: Ascomata gregarious to scattered, immersed to erumpent through the host surface, globose to subglobose, dark brown to black, unilocular, with indistinct ostiole. Peridium thin to thick-walled, of equal thickness, composed of 3-5 layers of pseudoparenchymatous cells, outer layers comprising thick-walled cells, dark brown to black, arranged in a textura angularis, inner layers comprising hyaline cells of textura angularis to textura prismatica. Hamathecium composed of dense, filamentous, cellular pseudoparaphyses, distinctly septate, embedded in a hyaline gelatinous matrix. Asci 8-spored, bitunicate, fissitunicate, broadly cylindrical to cylindric-clavate, short pedicellate, with obtuse pedicel, apically rounded, with a well-developed ocular chamber. Ascospores overlapping 1-2seriate, phragmosporous to muriform, fusiform to ellipsoidal, widest at the central cells, pale yellowish when young, becoming golden brown at maturity, 3 transverse septa, and 1 longitudinal septum in the $2^{\text {nd }}$ and $3^{\text {rd }}$ cells, constricted at the central septum, rounded to acute at both ends, rough-walled, finely verruculose, surrounded by a thick, hyaline, mucilaginous sheath. Asexual morph: Coelomycetous. Conidiomata, solitary, immersed to erumpent, dark brown to black, globose to subglobose, slightly depressed, unilocular, lacking ostiole. Pycnidial walls composed of 4-5 layers of thin-walled, brown to dark brown pseudoparenchymatous cells of textura angularis, inner layer with hyaline cells. Conidiophores reduced to conidiogenous cells. Conidiogenous cells enteroblastic, phialidic, integrated to discrete, doliiform, lageniform or cylindrical, smooth, hyaline, thin-walled, arising from the basal cavity. Conidia ellipsoidal to obovoid, truncate at the base, obtuse at the apex, muriform, brown to dark brown at maturity, 3 transverse septa, with 1 longitudinal septum at the $2^{\text {nd }}$ and the $3^{\text {rd }}$ cell, continuous or constricted at the septa, rough-walled.

Type species - Yunnanensis phragmitis A. Karunarathna, Phookamsak \& K. D Hyde, sp. nov.

Notes - Yunnanensis is introduced to accommodate Yunnanensis phragmitis. Yunnanensis is distinct from its sister taxa in having muriform ascospores with a mucilaginous sheath.

Yunnanensis phragmitis A. Karunarathna, Phookamsak \& K. D Hyde, sp. nov.

Figs 2, 3 Index Fungorum number: IF553843; Facesoffungi number: FoF03726

Etymology - Refers to the host, on which the asexual morph of the taxon was collected.

Holotype - MFLU 17-0357

Saprobic on Phragmites australis (Cav.) Trin. ex Steud and unidentified grass. Sexual morph: Ascomata 100-130 $\mu \mathrm{m}$ high, 115-170 $\mu \mathrm{m}$ diam., gregarious to scattered, immersed to erumpent through the host surface, globose to subglobose, dark brown to black, unilocular, with indisinct ostiole. Peridium 7-12 $\mu \mathrm{m}$ wide, thin to thick-walled, of equal thickness, composed of 3-5 layers of pseudoparenchymatous cells, outer layers comprising thick-walled cells, filamentous, cellular pseudoparaphyses, distinctly septate, embedded in a hyaline gelatinous matrix. Asci $61-113 \times 23-$ 
$31 \mu \mathrm{m}(\bar{x}=83 \times 28 \mu \mathrm{m}, \mathrm{n}=30), 8$-spored, bitunicate, fissitunicate, broadly cylindrical to cylindricclavate, short pedicellate, with obtuse pedicel, apically rounded, with a well-developed ocular chamber. Ascospores 11-13 $\times 4-7 \mu \mathrm{m}(\bar{x}=12 \times 6 \mu \mathrm{m}, \mathrm{n}=40)$, overlapping 1-2-seriate, phragmosporous to muriform, fusiform to ellipsoidal, widest at the central cells, pale yellow when young, becoming golden brown at maturity, 3 transverse septa, and 1 longitudinal septum in the $2^{\text {nd }}$ and $3^{\text {rd }}$ cells, constricted at the central septum, rounded to acute at both ends, rough-walled, finely verruculose, surrounded by a thick, hyaline, mucilaginous sheath. Asexual morph: Coelomycetous. Conidiomata $71-72 \mu \mathrm{m}$ high $\times 81-83 \mu \mathrm{m}$ diam. $(\bar{x}=72 \times 82 \mu \mathrm{m}, \mathrm{n}=8)$, solitary, immersed to erumpent, dark brown to black, globose to subglobose, slightly depressed, unilocular, lacking ostiole. Pycnidial walls 6-11 $\mu \mathrm{m}$ wide, composed of 4-5 layers of thin-walled, brown to dark
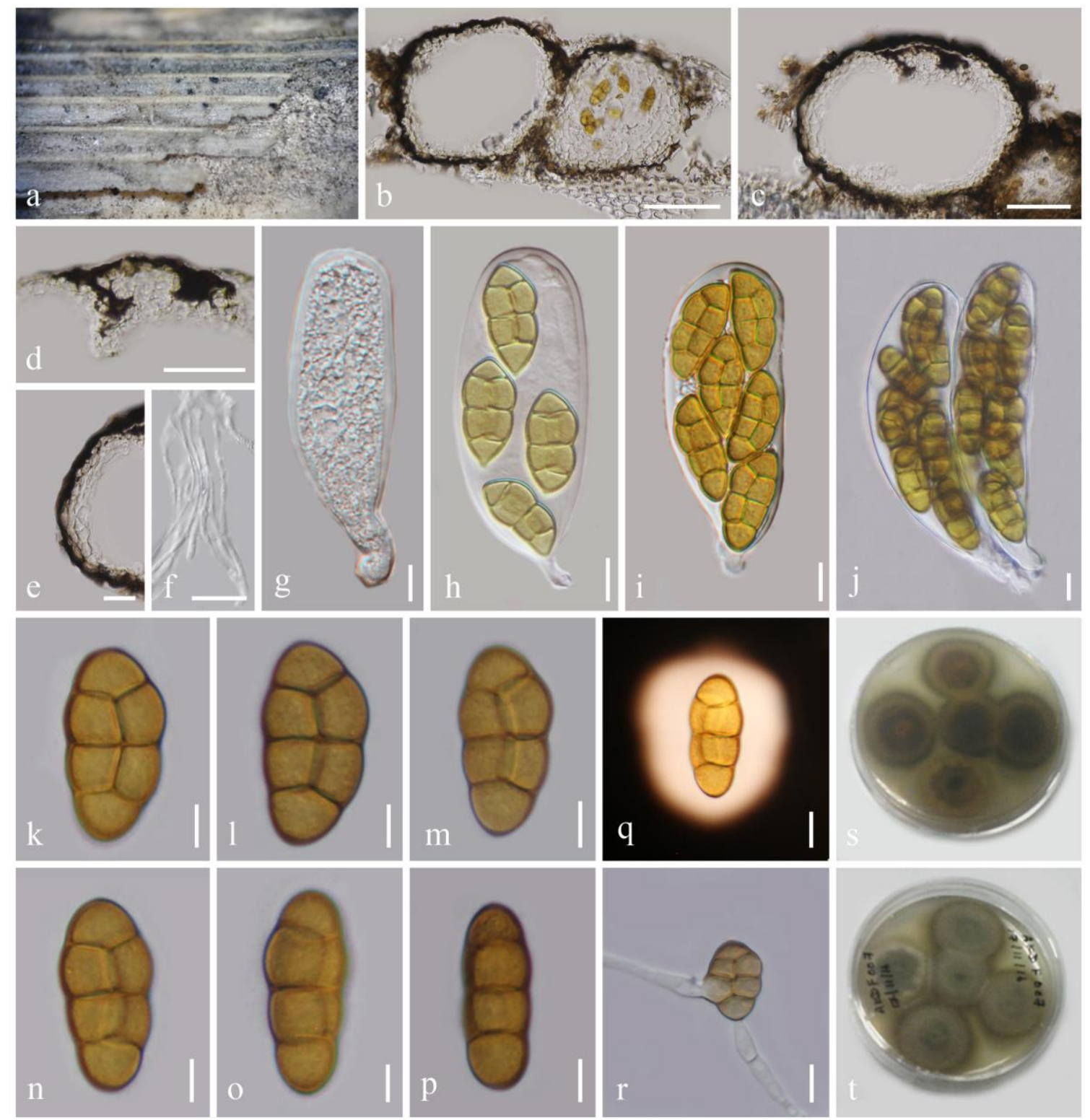

Figure 2 - Sexual morph of Yunnanensis phragmitis (MFLU 17-0357, holotype) a. Appearance of ascomata on the host. b-c. Section through ascomata. d. Section through an ostiole. e. Section through peridium. f. Pseudoparaphyses. g-j. Different developing stages of the asci. k-p. Ascospores. q. Ascospore surrounded by mucilaginous sheath, stained with Indian ink. $r$. Germinating ascospore. $s-t$. Culture characteristics on PDA $(s=$ from below, $t=$ from above). Scale bars: $\mathrm{b}-\mathrm{e}=50 \mu \mathrm{m}, \mathrm{f}-\mathrm{r}=10 \mu \mathrm{m}$. 
brown pseudoparenchymatous cells of textura angularis, inner layer with hyaline cells. Conidiophores reduced to conidiogenous cells. Conidiogenous cells $4-7 \mu \mathrm{m}$ high, $4-8 \mu \mathrm{m}$ wide $(\bar{x}$ $=6 \times 6 \mu \mathrm{m}, \mathrm{n}=8$ ), enteroblastic, phialidic, integrated to discrete, doliiform, lageniform or cylindrical, smooth, hyaline, thin-walled, arising from the basal cavity. Conidia 10-13 $\times 6-8 \mu \mathrm{m}$ $(\bar{x}=12 \times 7 \mu \mathrm{m}, \mathrm{n}=40)$, ellipsoidal to obovoid, truncate at the base, obtuse at the apex, muriform, brown to dark brown at maturity, 3 transverse septa, with 1 longitudinal septum, at the $2^{\text {nd }}$ or the $3^{\text {rd }}$ cell, continuous or constricted at the septa, rough-walled.

Culture characteristics - Sexual morph, colonies on PDA reaching 75-80 mm diam. after 3 weeks at $10-16^{\circ} \mathrm{C}$, colonies medium dense, circular, flat, surface slightly rough with edge entire, margin well-defined, glabrous to velvety with smooth aspects, colony from above pale green to grey, with white tufts; from below, yellowish brown at the margin, light brown at the centre; mycelium white to cream; not producing pigmentation in PDA media; asexual morph, colonies on PDA reaching $75-80 \mathrm{~mm}$ diam. after 3 weeks at $10-16^{\circ} \mathrm{C}$, colonies dense, circular, flat, surface rough with entire margin, cottony to velvety, colony from above white to pale brown, mycelium superficial, effuse, radially striate, from below, yellowish brown at the margin, light brown at the centre, mycelium white to cream; not producing pigmentation in PDA media.

Material examined - CHINA, Yunnan Province, Kunming, Kunming Institute of Botany, on stems of unidentified grass (Poaceae), 6 October 2016, A. Karunarathna, AKKIB 28 (MFLU 170363; HKAS 97356), ex-type living culture, MFLUCC 17-0315, KUMCC 16-0225; ibid. Dali, Erhai Lake, on stems of Phragmites australis (Poaceae) 28 November 2016, A. Karunarathna, AKDF 07 (MFLU 17-0357, holotype; HKAS 97348, isotype), ex-type living culture, MFLUCC 171361, KUMCC 16-0217. Additional GenBank numbers acquired: MF683624, MF683625.
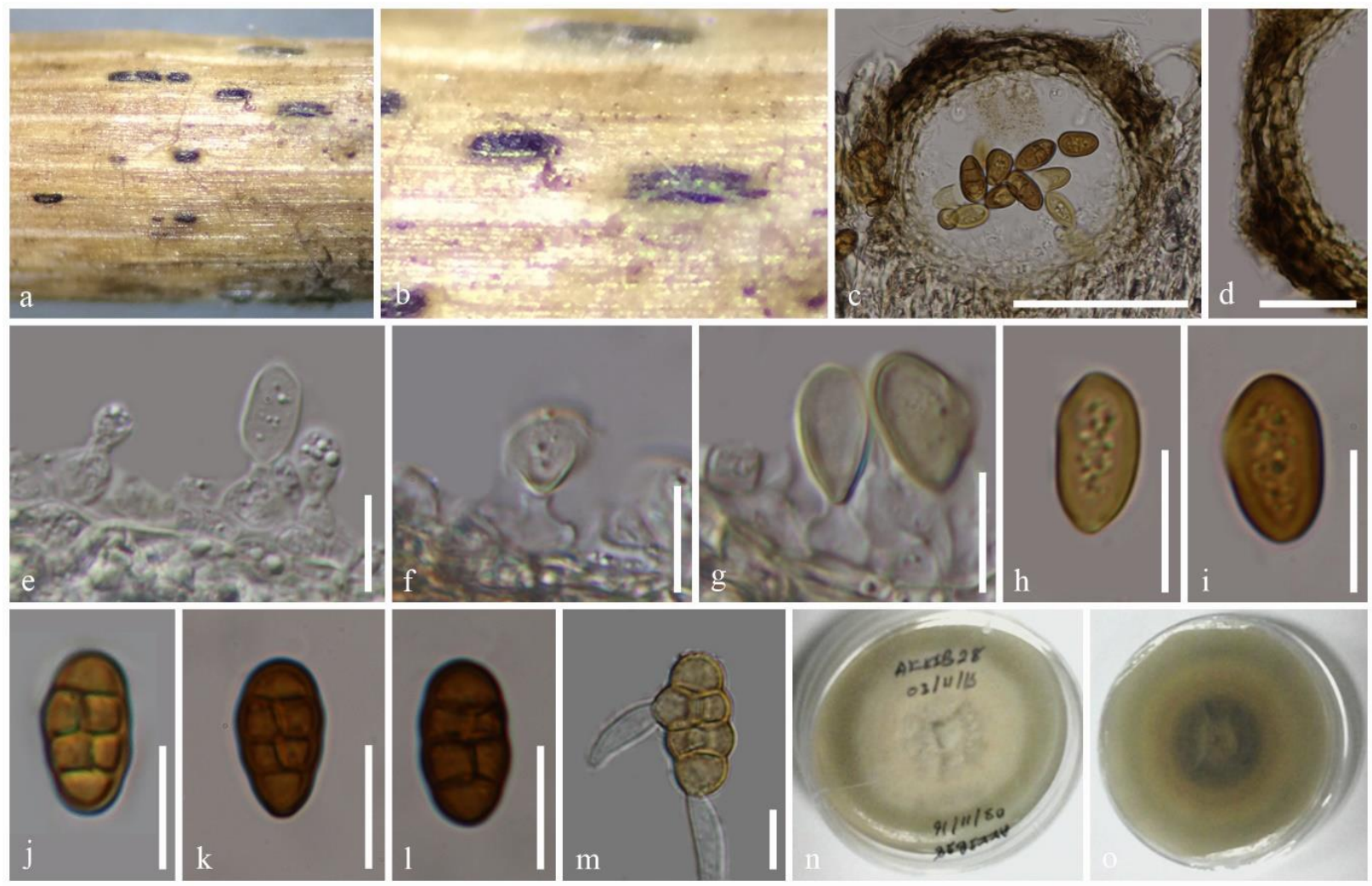

Figure 3 - Asexual morph of Yunnanensis phragmitis (MFLU 17-0363) a-b. Appearance of conidiomata on host substrate. c. Section of conidioma. d. Pycnidial wall. e-g. Conidiogenous cells and developing conidia. $\mathrm{h}-1$. Conidia. $\mathrm{m}$. Germinated conidium. $\mathrm{n}-\mathrm{o}$. Culture characteristics on PDA $(n=$ from above, $\mathrm{o}=$ from below). Scale bars: $\mathrm{c}=50 \mu \mathrm{m}, \mathrm{d}=50 \mu \mathrm{m}, \mathrm{e}-\mathrm{m}=10 \mu \mathrm{m}$.

Neosetophoma Gruyter, Aveskamp \& Verkley, in Gruyter et al., Mycologia 102(5): 1075 (2010) 
The genus Neosetophoma was introduced by de Gruyter et al. (2010) with Neosetophoma samarorum (Desm.) Gruyter, Aveskamp \& Verkley as the type species, which was found on Fraxinus excelsior L. (Oleaceae). Neosetophoma comprises five other species viz. N. clematidis Wijayaw., Camporesi \& K.D. Hyde, N. italica W.J. Li, Camporesi \& K.D. Hyde, N. lunariae Crous \& R.K. Schumach. N. garethjonesii Tibpromma, E.B.G. Jones \& K.D. Hyde and N. poaceicola Goonas., Thambugala \& K.D. Hyde (Index Fungorum 2017).

Neosetophoma iranianum Papizadeh, Amoozegar, Wijayaw., Shahzadeh Fazeli \& K.D. Hyde, sp. nov.

Index Fungorum number: IF553844; Facesoffungi number: FoF03724

Fig. 4

Etymology - Refers to Iran, where the holotype was collected.

Holotype - IBRC-H 2025

Soil fungus. Sexual morph: Undetermined. Asexual morph: Coelomycetous. Conidiomata (on PDA) 70-110 $\mu \mathrm{m}$ high, 75-120 $\mu \mathrm{m}$ diam, solitary, immersed to semi-immersed, dark brown to light brown, unilocular, pycnidial. Pycnidial walls 5-10 $\mu \mathrm{m}$ wide, composed of 2-3 cell layers of thin-walled, light brown to brown, textura angularis. Conidiophores reduced to conidiogenous cells. Conidiogenous cells 4-7 $\mu \mathrm{m}$ high, 2-4 $\mu \mathrm{m}$ wide, enteroblastic, phialidic, ampulliform, determinate, hyaline, smooth, thin-walled. Conidia 4-6 $2-4 \mu \mathrm{m}(\bar{x}=5 \times 3 \mu \mathrm{m}, \mathrm{n}=40)$, ellipsoidal to tear-drop shape (rarely pyriform), attenuate at the base, 1-3 transverse septa at maturity, yellow to light brown at maturity, continuous or constricted at the septa, smooth-walled.

Culture characteristics - Colonies on PDA, reaching 30-35 mm diam. after one month, white to yellowish in the first week, with central area becoming grey after three weeks, circular, dense, aerial, reverse dark brown, filamentous. Colonies on malt extract agar (MEA), pale grey to almost white, reverse dark brown, without any pigments produced. Colonies on corn meal agar, oat meal agar (OMA) and PDA umbonate, slowly-growing. On OMA surface white, on CMA and PDA surface light creamy reaching 11-12, 12-13, and 13-14 mm in diam. after 7 days of incubation at $25{ }^{\circ} \mathrm{C}$ on PDA, CMA and OMA, respectively. Pycnidia observed only on CMA and OMA.

Materials examined - IRAN, Golestan Province, Gomishan wetland, soil, in 2014, M. Papizadeh, IBRC-H 2025 holotype, ex-type living culture, IBRC-M 30176.

Notes - Neosetophoma iranianum is distinct in having subglobose, ovoid to tear-drop shaped, transversely $2-3$-septate conidia at maturity.

Wojnowiciella Crous, M. Hern.-Restr. \& M.J. Wingf., Persoonia 34: 201 (2015)

The genus was introduced by Crous et al. (2015b) to accommodate Wojnowiciella eucalypti Crous, Hern.-Restr. \& M.J. Wingf. and synonymized Wojnowiciella viburni (Wijayaw., Yong Wang bis \& K.D. Hyde) Crous, Hern.-Restr. \& M.J. Wingf.

Wojnowiciella dactylidis (Wijayaw., Camporesi \& K.D. Hyde) Hern.-Restr. \& Crous (2016) Fig. 5

Saprobic on Asperula sp. (Rubiaceae). Sexual morph: Ascomata 70-95 $\mu \mathrm{m}$ high, 65-85 $\mu \mathrm{m}$ diam., dark brown to black, solitary, scattered, semi-immersed, slightly raised on the host surface, globose to subglobose, lacking ostiole. Peridium 8-11 $\mu \mathrm{m}$ wide, thin -walled, composed of 1-5 cell layers, of large, brown, pseudoparenchymatous cells, of textura angularis. Asci 40-60 × 10-15 $\mu \mathrm{m}$ $(\bar{x}=49 \times 12 \mu \mathrm{m}, \mathrm{n}=20), 8$-spored, bitunicate, broadly cylindrical to sub-obclavate, short pedicellate, with indistinct ocular chamber. Ascospores 13-16 $\times 3-4.5 \mu \mathrm{m}(\bar{x}=14 \times 3.9 \mu \mathrm{m}, \mathrm{n}=$ 20 ), overlapping 1-2-seriate, hyaline, fusiform, with acute ends, upper cell widely pointed, lower cell narrowly pointed, 1-septate, slightly constricted at the septum, smooth-walled Asexual morph: Described in Liu et al. (2015).

Culture characteristics - Colonies growing on MEA becoming $2 \mathrm{~cm}$ within 10 days at $18{ }^{\circ} \mathrm{C}$, circular, flat, cottony, irregular margin, with less aerial mycelium, olivaceous green from above and dark brown from below, media becoming pinkish with age. 
Material examined - ITALY, Province of Forlì-Cesena [FC], Verghereto, Maestà della Biancarda, on dead aerial stem of Asperula sp. (Rubiaceae), 15 May 2013, E. Camporesi, IT 1265 (MFLU 14-0151), living cultures, MFLUCC 13-0799.

Notes - Based on a multi-gene phylogeny herein, our strain MFLUCC 13-0799 groups with Wojnowiciella dactylidis (MFLUCC 13-0735) with high support values (92\% ML/ 91\% MP/ 0.95 BYPP) and have $100 \%$ base pair similarity in ITS (5.8S) regions. Phylogeny also supports that our taxon is $W$. dactylidis. This is the first record of a sexual morph of W. dactylidis.
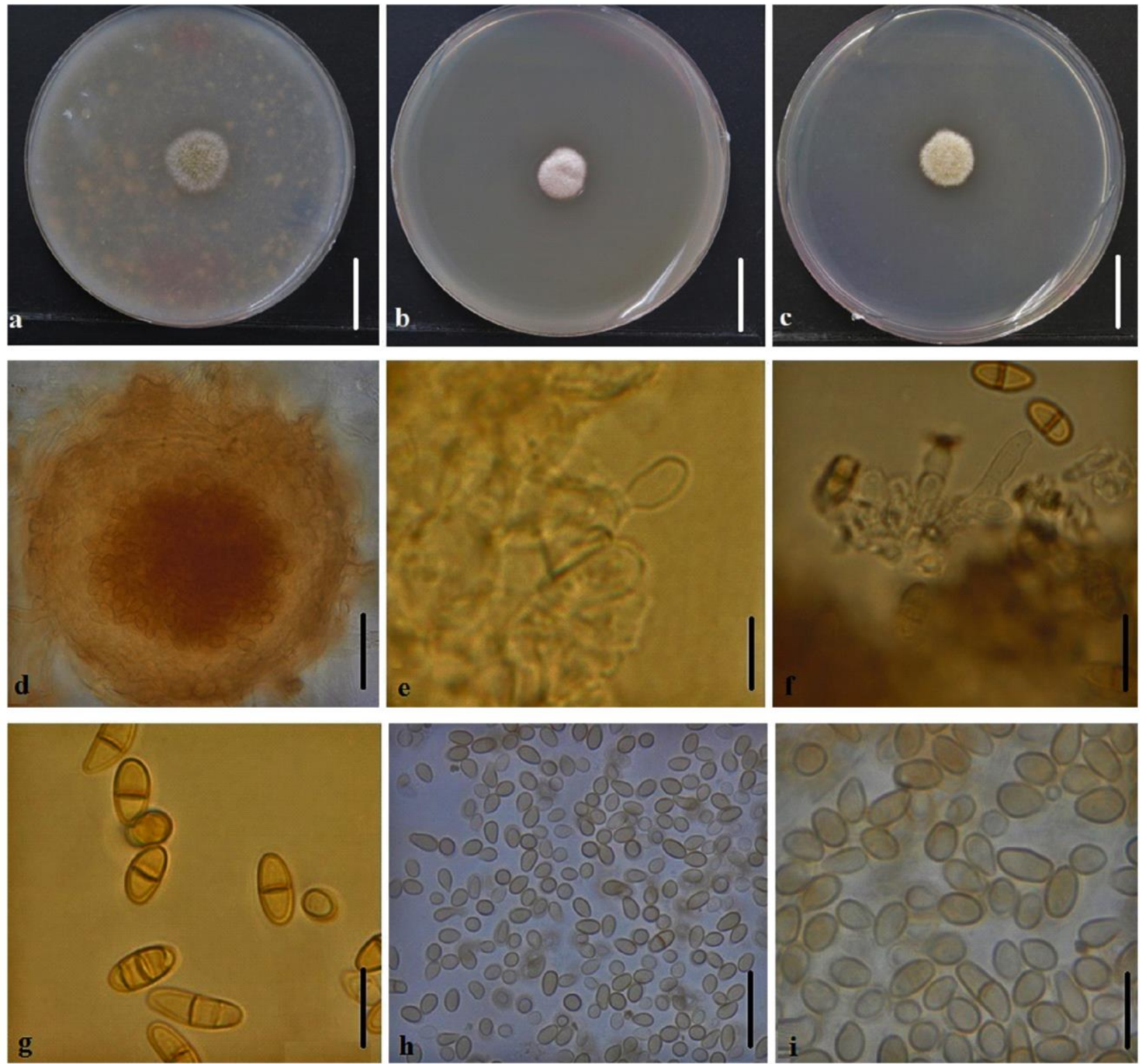

Figure 4 - Neosetophoma iranianum (IBRC-H 2025, holotype) a-c. Colonies on PDA, CMA and OA, respectively. d. Section through conidioma. e-f. Conidiogenous cells. g-i. Conidia. Scale bars: $\mathrm{a}-\mathrm{c}=1 \mathrm{~cm}, \mathrm{~d}=100 \mu \mathrm{m}, \mathrm{e}-\mathrm{i}=10 \mu \mathrm{m}$.

\section{Discussion}

Dothideomycetes on grasses can be pathogens, saprobes or endophytes, and are responsible for significant annual loss in crops (Ariyawansa et al. 2015b, Bakhshi et al. 2015, Liu et al. 2015, Wijayawardene et al. 2016, Thambugala et al. 2017). While fungal pathogens on grasses have been comparatively well-studied (Lamprecht et al. 2011, Manamgoda et al. 2012, 2015, Damm et al. 2014, Bakhshi et al. 2015), studies of saprobic fungi have been restricted to a few important hosts (Thambugala et al. 2017). However, several recent studies describing new taxa, are available for 
saprobes on grasses (Jayasiri et al. 2015b, Li et al. 2015b, Hyde et al. 2016, Karunarathna et al. 2017, Thambugala et al. 2017). Most fungi in Bambusicolaceae and Phaeosphaeriaceae are grass inhabiting (Quaedvlieg et al. 2013, Phookamsak et al. 2014a, b, Ariyawansa et al. 2015b, Liu et al. 2015, Hyde et al. 2016). In a recent study, Thambugala et al. (2017) introduced 50 new species and three new genera (Phaeopoacea, Kalmusibambusa, Neoramichloridium). $40 \%$ of which belonged to the Bambusicolaceae and Phaeosphaeriaceae.
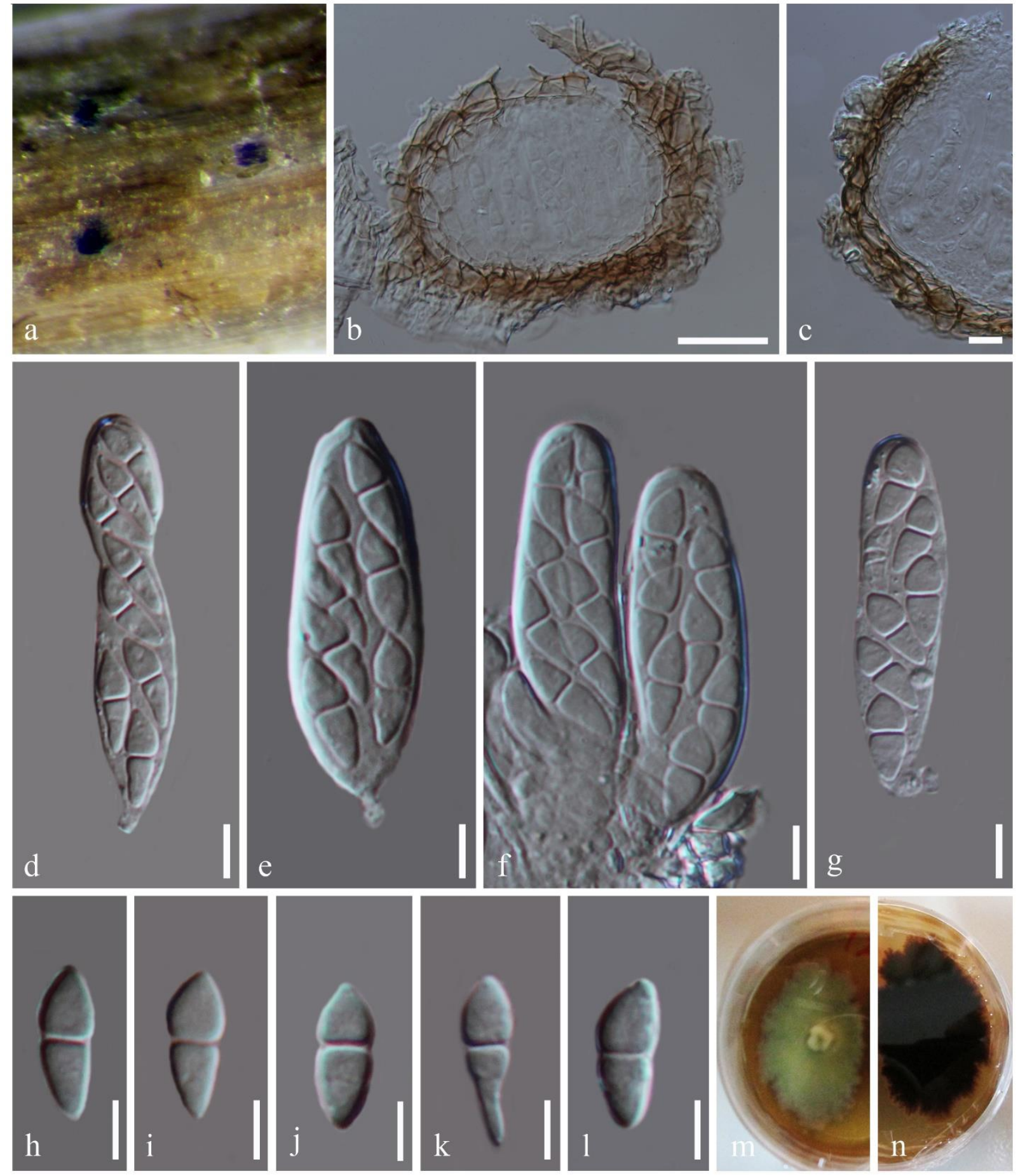

Figure 5 - Wojnowicia dactylidis (MFLU 14-0151, sexual morph). a. Ascomata on substrate. b. Cross section of ascoma. c. Peridium. d-g. Asci. h-l. Ascospores. $\mathrm{m}-\mathrm{n}$. Culture characteristics on PDA $(\mathrm{m}=$ from above, $\mathrm{n}=$ from below). Scale bars: $\mathrm{b}, \mathrm{c}=10 \mu \mathrm{m}, \mathrm{d}-\mathrm{g}=50 \mu \mathrm{m}, \mathrm{h}-1=5 \mu \mathrm{m}$. 
Table 1 Taxa used in the phylogenetic analyses and their corresponding GenBank numbers. Newly generated sequences are indicated in bold.

\begin{tabular}{|c|c|c|c|c|c|}
\hline \multirow{2}{*}{ Name } & \multirow{2}{*}{ Isolate/strain no. } & \multicolumn{3}{|c|}{ Accession number } & \multirow{2}{*}{ References } \\
\hline & & ITS & LSU & SSU & \\
\hline Allophaeosphaeria dactylidis & MFLUCC 13-0618 & KP744432 & KP744473 & KP753946 & Liu et al. 2015 \\
\hline Allophaeosphaeria subcylindrospora & MFLUCC $13-0380^{\mathbf{T}}$ & KT314184 & KT314183 & KT314185 & Ariyawansa et al. 2015a \\
\hline Amarenographium ammophilae & MFLUCC 16-0296 & KU848196 & KU848197 & KU848198 & Wijayawardene et al 2016 \\
\hline Equiseticola fusispora & MFLUCC $14-0522^{\mathrm{T}}$ & KU987668 & KU987669 & KU987670 & Abd-Elsalam et al. 2016 \\
\hline Galiicola dactylidicola & MFLUCC 13-0738 & KP744469 & KP684147 & KP684148 & Ariyawansa et al. 2015a \\
\hline Galiicola pseudophaeosphaeria & MFLU 14-0524 & KT326692 & KT326693 & NA & Liu et al. 2015 \\
\hline Leptosphaeria doliolum & CBS 505.75 & JF740205 & GQ387576 & GQ387515 & Schoch et al. 2009, de Gruyter et al. 2010, 2013 \\
\hline Melnikia anthoxanthii & MFLUCC $14-1010^{\mathbf{T}}$ & NA & KU848204 & KU848205 & Wijayawardene et al. 2016 \\
\hline Neosetophoma clematidis & MFLUCC 13-0734 ${ }^{\mathrm{T}}$ & KP744450 & KP684153 & KP684154 & Liu et al. 2015 \\
\hline Neosetophoma garethjonesii & MFLUCC 14-0528 & KY496758 & KY496738 & KY501126 & Tibpromma et al. 2017 \\
\hline Neosetophoma iranianium & IBRC $30176^{T}$ & MF684861 & MF684866 & MF684868 & In this study \\
\hline Neosetophoma italica & MFLU 14-C0809 & KP711356 & KP711361 & KP711366 & Liu et al. 2015 \\
\hline Neosetophoma lunariae & CPC $26671^{\mathrm{T}}$ & KX306763 & KX306789 & NA & Hernández-Restrepo et al. 2016 \\
\hline Neosetophoma poeceicola & MFLUCC 15-0886 & KY568986 & KY550382 & KY550383 & Thambugala et al. 2017 \\
\hline Neosetophoma samarorum & CBS $138.96^{\mathbf{T}}$ & FJ427061 & KF251664 & GQ387517 & Aveskamp et al. 2009 \\
\hline Ophiosphaerella aquaticus & MFLUCC 14-0033 & KX767088 & KX767089 & KX767090 & Ariyawansa et al. $2015 \mathrm{a}$ \\
\hline Paraleptosphaeria dryadis & CBS 643.86 & JF740213 & GU301828 & KC584632 & Schoch et al. 2009, de Gruyter et al. 2013, Woudenberg et al. 2013 \\
\hline Paraphoma chrysanthemicola & CBS $522.66^{\mathbf{T}}$ & FJ426985 & KF251670 & GQ387521 & Quaedvlieg et al. 2013 \\
\hline Paraphoma radicina & CBS $111.79^{\mathbf{T}}$ & FJ427058 & EU754191 & EU754092 & Aveskamp et al. 2009, de Gruyter et al. 2009, Quaedvlieg et al. 2013 \\
\hline Parastagonospora minima & MFLUCC 13-0376 & KU058713 & KU058723 & NA & Li et al. $2015 \mathrm{a}$ \\
\hline Parastagonospora nodorum & CBS $110109^{\mathbf{T}}$ & KF251177 & EU754175 & EU754076 & de Gruyter et al. 2009, Quaedvlieg et al. 2013 \\
\hline Phaeosphaeria chiangraina & MFLUCC $13-0231^{\mathbf{T}}$ & KM434270 & KM434280 & KM434289 & Phookamsak et al. 2014a \\
\hline Phaeosphaeria oryzae & CBS $110110^{\mathbf{T}}$ & KF251186 & KF251689 & GQ387530 & de Gruyter et al. 2009, Quaedvlieg et al. 2013 \\
\hline Poaceicola arundinis & MFLUCC $15-0702^{\mathrm{T}}$ & KU058716 & KU058726 & NA & Li et al. $2015 \mathrm{a}$ \\
\hline Poaceicola italica & MFLUCC $13-0267^{\mathbf{T}}$ & KX926421 & KX910094 & KX950409 & Thambugala et al. 2017 \\
\hline Sclerostagonospora opuntiae & CBS 118224 & JX517284 & JX517293 & NA & Crous et al. 2012 \\
\hline
\end{tabular}


Table 1 Continued.

\begin{tabular}{|c|c|c|c|c|c|}
\hline \multirow{2}{*}{ Name } & \multirow{2}{*}{ Isolate/strain no. } & \multicolumn{3}{|c|}{ Accession number } & \multirow{2}{*}{ References } \\
\hline & & ITS & LSU & SSU & \\
\hline Sclerostagonospora sp. & CBS 118152 & JX517283 & JX517292 & NA & Crous et al. 2012 \\
\hline Septoriella allojunci & MFLUCC $15-0701^{\mathbf{T}}$ & KU058718 & KU058728 & KT333437 & Ariyawansa et al. 2015a, Li et al. 2015a \\
\hline Septoriella phragmitis & CPC $24118^{\mathrm{T}}$ & KR873251 & KR873279 & AJ496631 & Crous et al. 2015a \\
\hline Vagicola arundinis & MFLUCC 15-0046 & KY706140 & KY706130 & KY706135 & Thambugala et al. 2017 \\
\hline Wojnowicia lonicerae & MFLUCC 13-0737 & KP744471 & KP684151 & KP684152 & Liu et al. 2015 \\
\hline Wojnowicia spartii & MFLUCC 13-0402 & KU058719 & KU058729 & NA & Li et al. $2015 \mathrm{a}$ \\
\hline Wojnowiciella dactylidis & MFLUCC 13-0799 & MF680298 & MF680299 & MF680485 & In this study \\
\hline Wojnowiciella dactylidis & MFLUCC 13-0735 & KP744470 & KP684149 & KP684150 & Liu et al. 2015 \\
\hline Wojnowiciella eucalypti & CPC $25024^{\mathbf{T}}$ & KR476741 & KR476774 & NA & Crous et al. $2015 b$ \\
\hline Wojnowiciella viburni & MFLUCC 12-0733a & KC594286 & KC594287 & КC594288 & Wijayawardene et al. 2013 \\
\hline Xenoseptoria neosaccardoi & CBS 120.43 & KF251280 & KF251783 & NA & Quaedvlieg et al. 2013 \\
\hline Xenoseptoria neosaccardoi & CBS $128665^{T}$ & KF251281 & KF251784 & NA & Quaedvlieg et al. 2013 \\
\hline Yunnanensis phragmitis & MFLUCC 17-0315 & MF684862 & MF684863 & MF684867 & In this study \\
\hline Yunnanensis phragmitis & MFLUCC 17-1361 & MF684869 & MF684865 & MF684864 & In this study \\
\hline
\end{tabular}

TType strain.

NA: not available

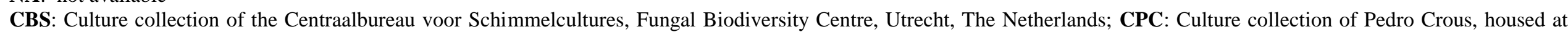
CBS-KNAW; IBRC: Microorganisms Bank of Iranian Biological Resource Center; MFLUCC: Mae Fah Luang University Culture Collection, Chiang Rai, Thailand.

The new genus Yunnanensis is morphologically typical of the Phaeosphaeriaceae in having globose to subglobose ascomata with thick peridium comprising with outer layer of textura angularis and inner layer of textura prismatica, bitunicate, fissitunicate asci with muriform ascospores comprises mucilaginous sheath.

The genus Yunnanensis, is distinct from its allied genus Neosetophoma in having muriform ascospores with mucilaginous sheath. The Phaeosphaeriaceae contains several genera with muriform ascospores and a comparison to Allophaeosphaeria, Dematiopleospora and Muriphaeosphaeria with Yunnanensis is given here.

Yunnanensis is distinct from Allophaeosphaeria by its ascomata which are composed of pseudoparenchymatous cells, with indistinct ostiole, whereas the ascomata of Allophaeosphaeria are composed of scleroplectenchymatous or pseudoparenchymatous cells with distinct ostiole (Liu et al. 2015). Asexual morph is not available for the type species of Allophaeosphaeria but was recorded in A. subcylindrospora W.J. Li, Camporesi \& 
K.D. Hyde, where the asexual morph is coelomycetous with cylindrical, 3-septate conidia (Ariyawansa et al. 2015a). However, the coelomycetous asexual morph of Yunnanensis has muriform conidia (Fig 3). Dematiopleospora has a unique character in having papillate ascomata, with thick brown periphyses inside the ostiole (Wanasinghe et al. 2014b). Yunnanensis is distinct from Muriphaeosphaeria in its asexual morph with ellipsoidal to obovoid, muriform conidia, whereas Muriphaeosphaeria has cylindrical to subclavate, phragmosporous conidia (Phukhamsakda et al. 2015). These genera are therefore morphologically distinct.

We noted that our two isolates of Yunnanensis phragmitis cluster together with high support but their relationships to Neosetophoma is poorly supported. Given that both Yunnanensis isolates constitute an independent lineage and they are characterized by specific morphs, establishment of a new genus is warranted. Pairwise comparison of DNA sequences of ITS regions between two isolates revealed very minor differences and hence we treat both as same species.

Neosetophoma iranianum, our new species is distinct from $N$. lunariae in having subglobose, ovoid to tear-drop shaped, 2-3-transversely septate conidia. Despite a close phylogenetic relatedness between the two species, pairwise dissimilarities of DNA sequences of ITS regions between $N$. iranianum and $N$. lunariae also provide further evidence to justify $N$. iranianum as a new species (Jeewon \& Hyde, 2016). Members of Neosetophoma have mostly been recorded as endophytic or saprobic on a range of host plants and this is the first time it was recorded from saline soils (Gomishan wetland is a brackish water body) (Saba et al. 2016a). The fungal diversity in such environments in Iran has been poorly studied. A few fungal taxa have been introduced from saline habitats in Iran including: Aspergillus iranicus Arzanlou et al., A. urmiensis Arzanlou et al. (Arzanlou et al. 2016), Emericellopsis persica Papizadeh et al. (Hyde et al. 2016), Neocamarosporium chichastianum Papizadeh et al. (Crous et al. 2014), N. jorjanensis Papizadeh et al., N. persepolisi Papizadeh et al., N. solicola Papizadeh et al. (Papizadeh et al. 2017b), and Purpureocillium sodanum Papizadeh et al. (Hyde et al. 2016).

Another interesting finding in this study is the phylogenetic association of two Wojnowiciella dactylidis isolates that cluster together with high bootstrap support. Wojnowiciella dactylidis MFLUCC 13-0735 was described as an asexual morph, whereas the new isolate of $W$. dactylidis MFLUCC 13-0799 is recovered from the sexual morph (Fig 5). Given the close phylogenetic relatedness, we consider both represent one species. Comparison of the ITS, LSU and SSU sequences also revealed a very high percentage of nucleotide similarity, which is indicative that they are one and the same species.

\section{Acknowledgements}

We appreciate the kind support given by the laboratory staff of Centre of Excellence in Fungal Research, Mae Fah Luang University, Chiang Rai, Thailand and Key Laboratory for Plant Diversity and Biogeography of East Asia, Kunming Institute of Botany, Chinese Academy of Sciences, Kunming, Yunnan, China. The Plant Germplasm and Genomics Center in Germplasm Bank of Wild Species, Kunming Institute of Botany is thanked for the molecular work. R Jeewon thanks University of Mauritius and Mae Fah Luang University for research support. R. Phookamsak expresses appreciation to The CAS President's International Fellowship for Postdoctoral Researchers, project number 2017PB0072, the Research Fund from China Postdoctoral Science Foundation (grant no. Y71B283261) and Chiang Mai University for financial support. Eric McKenzie thanks Chiang Mai University for the award of an Adjunct Professorship.

\section{References}

Abd-Elsalam KA, Tibpromma S, Wanasinghe DN, Camporesi E et al. 2016 - Equiseticola gen. Nov. (Phaeosphaeriaceae), from Equisetum sp. in Italy. Phytotaxa 284, 169-180.

Alef K, Nannipieri P. 1995 - Estimation of microbial activities In Methods in Soil Microbiology and Biochemistry Ed. Alef K, Nannipieri P. Academic Press, San Diego 214-215. 
Ariyawansa HA, Hyde KD, Jayasiri SC, Buyck B et al. 2015a - Fungal diversity notes 111-252taxonomic and phylogenetic contributions to fungal taxa. Fungal Diversity 75, 27-274.

Ariyawansa HA, Thambugala KM, Manamgoda DS, Jayawardena R et al. 2015b - Towards a natural classification and backbone tree for Pleosporaceae. Fungal Diversity 71, 85-139.

Arzanlou M, Samadi R, Frisvad JC, Houbraken J et al. 2016 - Two novel Aspergillus species from hypersaline soils of The National Park of Lake Urmia, Iran. Mycological Progress 15, 10811092.

Aveskamp MM, Verkley GJ, de Gruyter J, Murace MA et al 2009 - DNA phylogeny reveals polyphyly of Phoma section Peyronellaea and multiple taxonomic novelties. Mycologia 101, 363-82.

Bakhshi M, Arzanlou M, Babai-Ahari A, Groenewald JZ et al. 2015 - Application of the consolidated species concept to Cercospora spp. from Iran. Persoonia 34, 65-86.

Chomnunti P, Hongsanan S, Hudson BA, Tian Q et al. 2014 - The sooty moulds. Fungal Diversity 66, 1-36.

Crous PW, Carris LM, Giraldo A, Groenwald JZ et al. 2015a - The Genera of Fungi - fixing the application of the type species of generic names - G 2: Allantophomopsis, Latorua, Macrodiplodiopsis, Macrohilum, Milospium, Protostegia, Pyricularia, Robillarda, Rotula, Septoriella, Torula, and Wojnowicia. IMA Fungus 6, 163-198.

Crous PW, Groenewald JZ, Lombard L, Wingfield MJ. 2012 - Homortomyces gen. nov., a new dothidealean pycnidial fungus from the Cradle of Humankind. IMA Fungus 3, 109-115.

Crous PW, Wingfield MJ, Guarro J, Hernandez-Restrepo M et al. 2015b - Fungal Planet description sheets: 320-370. Persoonia 34, 167-266.

Crous PW, Wingfield MJ, Schumacher RK, Summerell BA et al. 2014 - Fungal Planet description sheets: 281-319. Persoonia 33, 212-289.

Damm U, O'Connell RJ, Groenewald JZ, Crous PW. 2014 - The Colletotrichum destructivum species complex-hemibiotrophic pathogens of forage and field crops. Studies in Mycology $79,49-84$.

de Gruyter, Aveskamp MM, Woudenberg JH, Verkley GJ et al. 2009 - Molecular phylogeny of Phoma and allied anamorph genera: towards a reclassification of the Phoma complex. Mycological Research 113, 508-519.

de Gruyter, Woudenberg JHC, Aveskamp MM, Verkley GJM et al. 2010 - Systematic reappraisal of species in Phoma section Paraphoma, Pyrenochaeta and Pleurophoma. Mycologia 102, 1066-1081.

de Gruyter, Woudenberg JHC, Aveskamp MM, Verkley GJM et al. 2013 - Redisposition of phoma-like anamorphs in Pleosporales. Studies in Mycology 75, 1-36.

Hall TA. 1999 - BioEdit: a user-friendly biological sequence alignment editor and analysis program for Windows 95/98/NT. In: Nucleic Acids. Symposium Series, 41. 95-98.

Hawksworth DL, Rossman AY. 1997 - Where are all the undescribed Fungi? Phytopathology 87, 888-891.

Hernández-Restrepo M, Schumacher RK, Wingfield MJ, Ahmad I et al. 2016 - Fungal Systematics and Evolution: FUSE 2. Sydowia 68, 193-230.

Huelsenbeck JP, Ronquist F. 2001 - MRBAYES: Bayesian inference of phylogenetic trees. Bioinformatics 17, 754-755.

Hyde KD, Hongsanan S, Jeewon R, Bhat DJ et al. 2016 - Fungal diversity notes 367-491: taxonomic and phylogenetic contributions to fungal taxa. Fungal Diversity 80, 1-270.

Hyde KD, Jones EBG, Liu JK, Ariyawansa H et al. 2013 - Families of Dothideomycetes. Fungal Diversity 63, 1-313.

Index Fungorum - 2017 http://www.indexfungorum.org/Names/Names.asp

Jayasiri SC, Hyde KD, Ariyawansa HA, Bhat DJ et al. 2015a - The faces of fungi database: fungal names linked with morphology, phylogeny and human impacts. Fungal Diversity 74, 3-18.

Jayasiri SC, Wanasinghe DN, Ariyawansa HA, Jones EBG et al. 2015b - Two novel species of Vagicola (Phaeosphaeriaceae) from Italy. Mycosphere 6, 716-728. 
Jeewon R, Hyde KD. 2016 - Establishing species boundaries and new taxa among fungi: recommendations to resolve taxonomic ambiguities. Mycosphere 7, 1669-1677.

Karunarathna A, Phookamsak R, Wanasinghe DN, Wijayawardene NN et al. 2017 - Taxonomy and phylogeny of Sparticola muriformis sp. nov. on decaying grass. Mycosphere 8, 603-614.

Katoh K, Rozewicki J, Yamada KD. 2017 - MAFFT online service: multiple sequence alignment, interactive sequence choice and visualization. Brief. Bioinform bbx108. https://doi.org/10.1093/bib/bbx108.

Kishino H, Hasegawa M. 1989 - Evaluation of the maximum likelihood estimate of the evolutionary tree topologies from DNA sequence data, and the branching order in hominoidea. Journal of Molecular Evolution 29, 170-179.

Lamprecht SC, Crous PW, Groenewald JZ, Tewoldemedhin YT et al. 2011 - Diaporthaceae associated with root and crown rot of maize. IMA fungus 2, 13-24.

Li GJ, Hyde KD, Zhao RN, Hongsanan S et al. 2016 - Fungal diversity notes 253-366: taxonomic and phylogenetic contributions to fungal taxa. Fungal Diversity 78, 1-237.

Li WJ, Bhat DJ, Camporesi E, Tian Q et al. 2015a - New asexual morph taxa in Phaeosphaeriaceae. Mycosphere 6, 681-708.

Li WJ, Maharachchikumbura SSN, Li QR, Bhat DJ et al. 2015b - Epitypification of Broomella vitalbae and introduction of a novel species of Hyalotiella. Cryptogamie Mycologie 36, 93108.

Liu JK, Hyde KD, Gareth EBG, Ariyawansa HA et al. 2015 - Fungal diversity notes 1-110: taxonomic and phylogenetic contributions to fungal species. Fungal Diversity 72, 1-197.

Liu JK, Hyde KD, Jeewon R, Phillips AJL et al. 2017 - Ranking higher taxa using divergence times: a case study in Dothideomycetes. Fungal Diversity 84, 75-99.

Manamgoda DS, Cai L, McKenzie EHC, Crous PW et al. 2012 - A phylogenetic and taxonomic reevaluation of the Bipolaris-Cochliobolus-Curvularia complex. Fungal Diversity 56, 131144.

Manamgoda DS, Rossman AY, Castlebury LA, Chukeatirote E et al. 2015 - A taxonomic and phylogenetic re-appraisal of the genus Curvularia (Pleosporaceae): human and plant pathogens. Phytotaxa 212, 175-198.

Miller MA, Pfeiffer W, Schwartz T. 2010 - Creating the CIPRES Science Gateway for Inference of Large Phylogenetic Trees. In: SC10 Workshop on Gateway Computing Environments (GCE10).

Nylander JAA. 2004 - MrModeltest v2. Program distributed by the author. Evolutionary Biology.

Papizadeh M, Roayaei Ardakani M, Motamedi H 2017a - Growth-phase dependent biodesulfurization of dibenzothiophene by Enterobacter sp. strain NISOC-03. Pollution $3,101-111$.

Papizadeh M, Wijayawardene NN, Amoozegar MA, Saba F et al. 2017b - Neocamarosporium jorjanensis, $N$. persepolisi and $N$. solicola spp. nov. (Neocamarosporiaceae, Pleosporales) isolated from saline lakes of Iran indicate the possible halotolerant nature for the genus. Mycological Progress. https://doi.org/10.1007/s11557-017-1341-x.

Phookamsak R, Liu JK, Manamgoda DS, Chukeatirote E et al. 2014b - The sexual state of Setophoma. Phytotaxa 176, 260-269.

Phookamsak R, Liu JK, McKenzie EHC, Manamgoda DS et al. 2014a - Revision of Phaeosphaeriaceae. Fungal Diversity 68, 159-238.

Phukhamsakda C, Ariyawansa HA, Phookamsak R, Chomnunti P et al. 2015 - Muriphaeosphaeria galatellae gen. et sp. nov. in Phaeosphaeriaceae (Pleosporales). Phytotaxa 227, 55-65.

Phukhamsakda C, Hongsanan S, Ryberg M, Ariyawansa HA et al. 2016 - The evolution of Massarineae with Longipedicellataceae fam. nov. Mycosphere 7, 1713-1731.

Poon MOK, Hyde KD. 1998 - Biodiversity of intertidal estuarine fungi on Phragmites at Mai Po marshes, Hong Kong. Botanica Marina 41, 141-155.

Purahong W, Hyde KD. 2011 - Effects of fungal endophytes on grass and non-grass litter decomposition rates. Fungal Diversity 47, 1-7. 
Quaedvlieg W, Verkley GJM, Shin HD, Barreto RW et al. 2013 - Sizing up Septoria. Studies in Mycology 75, 307-390.

Rambaut A, Suchard MA, Xie D, Drummond AJ. 2014 - Tracer v1.6. Available from http://beast.bio.ed.ac.uk/Tracer.

Rambaut A. 2012 - FigTree version 1.4.0. Available at: http://tree.bio.ed.ac.uk/software/figtree/

Rannala B, Yang Z. 1996 - Probability distribution of molecular evolutionary trees: a new method of phylogenetic inference. Journal of Molecular Evolution 43, 304-311.

Saba F, Noroozi M, Ghahremaninejad F, Amoozegar MA et al. 2016a - Isolation, purification and identification of three diatom species (Bacillariophyceae) from Gomishan wetland (N. Iran) using phylogeny and silica cell wall ultra-structure analysis. Rostaniha 17, 28-39.

Saba F, Papizadeh M, Khansha J, Sedghi M et al. 2016b - A rapid and reproducible genomic DNA extraction protocol for sequence-based identifications of archaea, bacteria, cyanobacteria, diatoms, fungi, and green algae. Journal of Medical Bacteriology 5, 22-28.

Schoch CL, Crous PW, Groenewald JZ, Boehm EWA et al. 2009 - A class-wide phylogenetic assessment of Dothideomycetes. Studies in Mycology 64, 1-15.

Stamatakis A, Hoover P, Rougemont J. 2008 - A rapid bootstrap algorithm for the RAxML web servers. Systematic Biology 57, 758-771.

Stamatakis A. 2014 - RAxML version 8: a tool for phylogenetic analysis and post-analysis of large phylogenies. Bioinformatics 30, 1312-1313.

Swofford DL. 2002 - PAUP: phylogenetic analysis using parsimony, version 4.0 b10. Sinauer Associates, Sunderland.

Thambugala KM, Wanasinghe DN, Phillips AJL, Camporesi E et al. 2017 - Mycosphere notes 150: grass (Poaceae) inhabiting Dothideomycetes. Mycosphere 8, 697-796.

Tibpromma S, Hyde KD, Jeewon R, Maharachchikumbura S et al. 2017 - Fungal diversity notes 491-602: taxonomic and phylogenetic contributions to fungal taxa. Fungal Diversity 83, 1261.

Vilgalys R, Hester M. 1990 - Rapid genetic identification and mapping of enzymatically amplified ribosomal DNA from several Cryptococcus species. Journal of Bacteriology 172, 4238-4246.

Wanasinghe DN, Hyde KD, Jeewon R, Crous PW. Et al. 2017a - Phylogenetic revision of Camarosporium (Pleosporineae, Dothideomycetes) and allied genera. Studies in Mycology 87, 207-256.

Wanasinghe DN, Jones EBG, Camporesi E, Boonmee S et al. 2014a - An exciting novel member of Lentitheciaceae in Italy from Clematis vitalba. Cryptogamie Mycologie 35, 323-337.

Wanasinghe DN, Jones EBG, Camporesi E, Boonmee S et al. 2014b - Dematiopleospora mariae gen. sp. nov., from Ononis Spinosa in Italy. Cryptogamie Mycologie 35,105-117.

Wanasinghe DN, Phookamsak R, Jeewon R, Wen Jing Li et al. 2017b - Fenestellaceae with descriptions of new Fenestella species and Neocucurbitaria gen. nov. Mycosphere 8, 397414.

White TJ, Bruns T, Lee S, Taylor J. 1990 - Amplification and direct sequencing of fungal ribosomal RNA genes for phylogenetics. In: Innis MA, Gelfand DH, Sninsky JJ, White TJ (eds), PCR Protocols: a guide to methods and amplifications. Academic Press, San Diego, CA, pp. 315-322.

Wijayawardene NN, Hyde KD, Wanasinghe DN, Papizadeh M et al. 2016 - Taxonomy and phylogeny of dematiaceous coelomycetes. Fungal Diversity 77, 1-316.

Wijayawardene NN, Song Y, Bhat DJ, McKenzie EHC et al. 2013 - Wojnowicia viburni, sp. nov., from China and its phylogenetic placement. Sydowia 65, 129-138.

Wong MKM, Hyde KD. 2001 - Diversity of fungi on six species of Gramineae and one species of Cyperaceae in Hong Kong. Mycological Research 105, 1485-1491.

Woudenberg JH, Groenewald JZ, Binder M, Crous PW 2013 - Alternaria redefined. Studies in Mycology 75, 171-212.

Zhaxybayeva O, Gogarten JP. 2002 - Bootstrap, Bayesian probability and maximum likelihood mapping: exploring new tools for comparative genome analyses. BMC Genomics 3, 4. 